\title{
NEOLIBERALISM AND GENDER EQUALITY: CANADIAN NEWSPAPERS' REPRESENTATIONS OF THE BAN OF FACE COVERINGS AT CITIZENSHIP CEREMONIES
}

\author{
Ivana Previsic ${ }^{1}$
}

\begin{abstract}
In late 2011, Canada's Conservative government banned face coverings for those taking oath at citizenship ceremonies. The ban was unequivocally interpreted by the press to be targeting veilwearing Muslim women. This paper analyzes newspaper coverage in the month following the announcement of the policy. It argues that most commentators conceptualized citizenship to be a neoliberal tool of rescuing veiled Muslim women from their male oppressors and making them more like the equal/neoliberal "us" and/or as a reward for those who already are or will become equal/neoliberal. Most non-Muslim commentators constructed gender oppression as the reason for which veiled women should (not) become citizens. Gender equality in Canada was represented as a key national value and inequality was erased or minimized and presented as a Muslim problem. In attempting to deflect these arguments, most Muslim commentators silenced gender inequality among Muslims by arguing that veiled Muslim women choose the practice and by relegating gender oppression to Western societies, thereby constructing veiled Muslim women as ideal neoliberal subjects worthy of Canadian citizenship.
\end{abstract}

\footnotetext{
${ }^{1}$ Ivana Previsic is a PhD candidate in the School of Sociological and Anthropological Studies at the University of Ottawa.
} 


\section{Introduction}

Muslims have been seen as antithetical to the predominantly Christian "West" ever since Islam's emergence in the 7th century (Said 1979). The series of terrorist attacks committed in the name of Islam in the years following 9/11 appear to have intensified this perceived divide. Muslims have been represented in Western public discourses as embodying values incongruent with those of the West, particularly in the areas of human rights and gender equality. Gendered practices associated with Muslims, namely female genital mutilation, honour killings, arranged marriages and the head and face coverings, have incited heated public debates about whether Muslims can "integrate" into supposedly gender-equal Western societies.

While internationally regarded as more welcoming and tolerant towards immigrants and minorities than Europe, Canada has had its share of controversies and policy proposals which centered in particular on the niqab, which has a small opening around the eyes and covers the face completely. For instance, in January 2007, the town of Herouxville, QC garnered international attention when its immigrants' code of conduct banned the stoning of women and covering of faces (Gagnon and Jiwani 2012). The same year, Elections Canada decided to allow those who cover their faces to vote (Abu-Laban 2013). In 2010, Quebec tabled Bill 94 which proposed to ban conspicuous religious symbols in Quebec's public service. The public debate on the bill revolved almost exclusively around the practice of face covering. While in 2012 the Supreme Court of Canada decided to leave the decision on whether to allow a witness to testify while wearing the niqab ${ }^{2}$, in 2013, an Ontario judge decided that the woman must remove the garment in order to testify ${ }^{3}$. The same year, Quebec's governing Parti Québécois (PQ) introduced "Projet de loi 60", known as the "Quebec Charter of Values", proposing to prevent state employees from wearing "conspicuous" religious symbols at work and to refuse to provide or to receive public services by those whose faces were covered (Shachar 2015, 325). The socalled "niqab bill" (Provost 2014) died with the PQ's defeat and the election of a Liberal government in 2014.

In late 2011, the Conservative government of Stephen Harper banned face coverings for people taking oath at citizenship ceremonies. In 2014, a permanent resident from Pakistan, Zunera Ishaq legally challenged the ban. In 2015, a federal judge ruled in her favour and two subsequent government appeals were denied. ${ }^{4}$ The ban was a major 2015 federal election campaign issue that may have contributed to the Conservatives' defeat, as well as the New Democratic Party's loss of support in Quebec due to the party's opposition to the measure. ${ }^{5}$ In November 2015, the newly elected Liberal government withdrew the appeal launched by the previous government. In her first act as Canada's Liberal justice minister, Jody Wilson-Raybould stated that "we will

\footnotetext{
2 Judgments of the Supreme Court of Canada, "R. v. N.S., 2012 SCC 72, [2012] 3 S.C.R. 726”, December 20, 2012 , accessed November 16, 2016, http://scc-csc.lexum.com/scc-csc/scc-csc/en/item/12779/index.do

${ }^{3}$ Canadian Legal Information Institute, “R. v. S.(M.), 2013 ONCJ 209”, April 24, 2013, accessed November 16, 2016, http://www.canlii.org/en/on/oncj/doc/2013/2013oncj209/2013oncj209.html

${ }^{4}$ Federal Court of Canada, "2015 FC 156”, February 6, 2015, accessed November 16, 2016, http://decisions.fctcf.gc.ca/fc-cf/decisions/en/item/108049/index.do?r=AAAAAQAMenVuZXJhIGlzaGFxAQ

${ }^{5}$ Tasker, John Paul, "NDP dropped 20 points in 48 hours after supporting niqab, Tom Mulcair says", CBC News, February 13, 2016, accessed March 21, 2016, http://www.cbc.ca/news/politics/thomas-mulcair-acceptsresponsibility-1.3446241.
} 
ensure that we respect the values that make us Canadians, those of diversity, inclusion and respect for those fundamental values". 6 This formally ended the issue of face coverings at citizenship ceremonies.

When the ban was initially announced, the Citizenship and Immigration Canada's Operational Bulletin 359 simply stated that citizenship candidates needed to be seen taking the Oath of Citizenship (CIC 2011a) ${ }^{7}$. Much less neutral was the language of then Minister of Citizenship and Immigration Jason Kenney "to segregate one group of Canadians or allow them to hide their faces, to hide their identity from us precisely when they are joining our community is contrary to Canada's commitment to openness and to social cohesion" (CIC 2011b).

This paper examines Canada's mainstream newspapers' coverage of the ban in the month following the announcement. Specifically, it analyzes how gender equality was employed by the commentators to argue their positions and conceptualize the meaning of Canadian citizenship. It is argued that a neoliberal understanding of gender (in)equality was employed to debate the ban, whereby both Muslim and non-Muslim commentators negated the existence of gender inequality among "us" and ascribed it instead to "them". Canadian citizenship was represented as worthy only of those women who were considered to already be gender equal or those who were en route to becoming gender equal, by virtue of revealing their faces to others.

In this paper, I first conceptualize the link between neoliberalism, citizenship and Muslim "others" and then provide an overview of recent research on the state of gender equality in Canada and the relations between the media and minorities. After outlining the methodological approach, I summarize and discuss the main findings.

\section{Neoliberal Citizenship and Muslim "Others"}

Neoliberalism is an aspect of capitalism that promotes "privatisation and deregulation in order to safeguard the freedom of the individual to compete and consume without interference from a bloated state" (Gupta 2012, 1). Most commonly associated with the governments of Margaret Thatcher and Ronald Reagan, the doctrine emerged in the 1980s as a response to "rising unemployment, inflation, and burgeoning government deficits" (Brodie 2008, 169). Placing the ultimate responsibility on the individual, neoliberal politics denies the existence of systemic group inequalities $(2008,178)$. Neoliberalism functions not only as a structuring principle of markets, but also as "an ethic in itself, capable of acting as a guide to all human action, and substituting for all previously held ethical beliefs" (Harvey 2007, 3). It is this view of neoliberalism as a "way of thinking" that guides the direction of this paper.

\footnotetext{
${ }^{6}$ Mas, Susana, "Justin Trudeau's government drops controversial niqab appeal”, CBC News, November 16, 2015 , accessed March 21, 2016, http://www.cbc.ca/news/politics/niqab-appeal-appeal-citizenship-ceremonies-canadajody-wilson-raybould-1.3321264.

${ }^{7}$ The link to the bulletin was removed from the CIC website when the new Liberal government dropped the appeal.

${ }^{8}$ Replaced by Chris Alexander in 2013
} 
Canada has been experiencing tangible effects of neoliberal restructuring since the 1980s and 1990s when governing structures diminished social programs and neglected issues such as reproductive labour, unpaid housework and childcare, as well as universal childcare (Jenson 2008). During that period, Canadian women's movements lost influence to "civil society groups, such as unions, anti-poverty movements, child care advocates, and other progressive forces" who, once their allies, became "almost silent" about the state of gender equality in Canada (Ibid 2008, 187). Today, the public sphere, purported to be genderless and motivated by self-interest, freedom and choice, remains divided from the private sphere in which domestic and caring labour remain unpaid and highly gendered (Brodie 2008, 171).

As a dominant system of thought and political movement, the neoliberal thinking has also redefined the image of an "ideal citizen". She or he is rational, self-owning, self-sufficient and personally responsible for their life outcomes (Abu-Laban and Gabriel 2002; Anderson 2013; Somers 2008). The ideal neoliberal citizen is one "without any sort of group-based identity" while "a non-citizen is someone who remains trapped within group-based identities" (Razack 2008, 166). The neoliberal logic thus considers those who claim a group-based identity or inequality based on belonging to an identity group unworthy of citizenship benefits.

This has had important implications for the ongoing struggle for gender equality in the West. The neoliberal reasoning discursively erases or minimizes the existence of gender inequality in two ways. First, any inequalities or social problems are attributed to individual failures, "missed opportunities, bad decisions, or unfortunate events", whilst structural inequalities such as gender and race are disregarded (Brodie 2008, 180). Second, "our" gender-based grievances are trivialized or muted when placed in comparison to gender inequalities of minority groups, Muslims in particular. As Thobani $(2007,108)$ argues, the presence of racialized "others" coming from "traditional", non-Western communities has greatly inflated the semblance of economic and symbolic inclusion of women in the nationhood. Indeed, as Yeğenoğlu $(1998,105)$ observed, "the declaration of an emancipated status for the Western woman is contingent upon the representation of the Oriental woman as her devalued other". Set in opposition to the "civilized European", "the dangerous Muslim man", as the perpetrator of gender inequality, and "the imperiled Muslim woman" as the helpless victim, have been constructed as the quintessential embodiments of illiberal, gender-unequal "others" (Razack 2008). Far from being consequential in discourse only, the "concern" about gender relations among Muslims, and particularly head and face coverings, deflects attention from debating the state of gender (in)equality in the West (Jiwani 2008, 133).

The ideal neoliberal citizen "without ties to community" presents "the conceptual underpinning for a number of repressive measures" including the recasting of citizenship laws, for instance, the introduction of citizenship tests and cultural codes of conduct (Fekete 2004, 4). A European example includes the Netherlands' "integration exam" for foreigners looking to marry or reunite with their family. A component of the test is a film which, among other themes, presents Netherlands' gender equality as absolute and ignores, "persistent inequalities in the fields of labour, childcare, household and continuing experience of gender based harassment and violence [and] institutional sexism" (de Leeuw and van Wichelen 2012, 98). Canadian examples include the new citizenship guide which uses the word "barbaric" to qualify "spousal abuse, "honour killings', female genital mutilation, forced marriage or other gender-based violence" (Canada 2011; Winter and Sauvageau 2014) and the ban of face coverings at citizenship ceremonies 
which has been interpreted as targeting specifically niqab-wearing Muslim women (Thomas 2015; Park 2013). As Razack argues, in order to attain full citizenship in Western societies, Muslims are expected to change and "just assimilate" $(2008,166)$. Failure to do so justifies the state in "keeping Muslims out or limiting their citizenship rights" (Ibid, 166). The participation of Muslims in citizenship thus "become[s] dependent on a willingness to transcend these dualisms by picking a side" (Fernandez 2009, 270).

\section{(Muslim) Women in Canada}

Head and face coverings have been portrayed by Western political and media discourses as an example par excellence of gender subjugation among Muslims and an affront to Western values of gender equality (Clarke 2013; Jiwani 2008; McDonough 2003a; McDonough and Hoodfar 2005; Roald 2002; Zine 2012). However, research on the experiences of Muslim women in the West shows that the motives behind the practice are varied and context-dependent. The reasons for wearing both the hijab (which covers only the hair) and niqab (which also covers the face except the eyes) include free choice based on religious obligation, dignity, deterring unwanted sexual attention, empowerment, confidence, self-esteem and freedom from the pressures of fashion (Ahmed 2011; Borghée 2012; Bowen 2007; Clarke 2013; Hoodfar 2003; McDonough 2003b; Ruby 2006). With respect specifically to the niqab, research shows that some women indeed wear it on the insistence of their male family members, while others report having encountered family opposition to their decision to cover their faces (Clarke 2013; Hoodfar 2003).

At the same time, gender equality in the West, including in Canada, is far from being a done deed. While women have made significant gains in their struggle for gender equality in the last half-century, they have not reached parity in earnings, full-time work, political engagement or domestic work and childcare time allocation (Ferrao 2010; Milan et al. 2010; Pay Equity Commission 2012; Vosko 2003). Gendered microaggressions in the form of overt sexism and subtle discrimination are a part of many women's daily interactions (Sue 2010). Women continue to be held to high beauty standards (Wolf 1991; 2002) and sexual objectification occurs within everyday life as well as in Canadian media representations (McGarry and Mannik 2015). With respect to gender violence and oppression, often associated with Muslims, it is estimated that one in three Canadian women will experience sexual assault in her adult life and more than 6 percent of women report being physically or sexually assaulted by a spousal partner (Ontario Women's Directorate 2013). Young women aged 15 to 19 are 10 times more likely to experience dating violence compared to young men (Status of Women 2015). In 2004, at least 200,000 Canadian women were physically assaulted and 106,000 were sexually assaulted by intimate partners (Johnson and Dawson 2011 in Rajiva and Khoday 2014, 174). Another 460,000 sexual assaults were committed by non-intimate partners. In 2008, 64 women were murdered by intimate partners. Approximately 100,000 women and children are admitted to emergency shelters every year (Ibid).

Gender oppression is clearly far from being confined to Muslims or other minority groups. Oppression and inequality, but also choice and emancipation coexist and intersect in everyday experiences of Muslim and non-Muslim women alike. Muslim and non-Muslim women in Canada have more in common in terms of experiencing gender inequality than what popular 
narratives have us believe. The following section outlines in more detail the role that the mainstream media play in the construction of these discourses.

\section{Muslims in the Mainstream Media}

In addition to "agenda-setting" - determining which issues are important for the consumers to consider (McCombs and Shaw 1972; Weaver 2007) - the mainstream media influence how we think about matters at hand (Fleras 2011). As producers and reproducers of dominant national and cultural narratives (Henry and Tator 2002; Van Dijk 1991), they play a pivotal role in shaping the citizens' "common sense" understanding of who belongs in the nation and who does not (Mahtani 2001). For researchers interested in "dominant discourses, rather than dissident or idiosyncratic voices", newspapers continue to represent the platform of choice (Mautner 2008, 32). While print readership is in decline, eight out of ten Canadians read newspapers each week and $70 \%$ of them read printed editions daily. ${ }^{9}$

Studies show that Western mainstream media have tended to portray minorities in a negative light (Fleras and Kunz 2001). Muslims in particular have been represented as threats to liberaldemocratic values and national security, in both Europe's ${ }^{10}$ and Canada's ${ }^{11}$ mainstream media. Muslim women, often in the context of head and face coverings, have been depicted by the media predominantly as oppressed and/or dangerous "others" (Antonius 2013; Bullock and Jaffri 2001; Byng 2010; Gagnon and Yiwani 2012; Jiwani 2006).

In their analyses of media representations of the ban of face coverings at citizenship ceremonies, Thomas (2015) and Park (2013) found that niqab-wearing women were portrayed both as victims and threats to Canadian society. Park, however, focused only on online comments and did not include an analysis of the opinions of Muslims, while Thomas analyzed the broad themes that the media employed in its coverage. This paper focuses specifically on how one theme gender equality - was utilized by both non-Muslims and Muslims in order to form their arguments for or against the ban and thereby conceptualize their understandings of Canadian citizenship.

\section{Methodology}

Newspaper articles were accessed using the two largest Canadian newspaper databases: Canadian Newsstand Major Dailies database for English and Eureka.cc for French content. The databases were searched for stories containing the words "citizenship" and "citoyenneté" which were published after December 12, 2011, when the ban was announced. 94 articles (Table 1) were identified which focused specifically on the ban. Most stories were published in the month following the announcement of the policy.

\footnotetext{
${ }^{9}$ Vividata, "Study: Print remains preferred magazine platform", November 8, 2016, accessed November 16, 2016, https://vividata.ca/news/vivintel-reports-newsletters/

${ }^{10}$ E.g. Bleich et al 2015; Fredette 2014; Geisser 2003; Meer, 2006; Petley and Richardson 2011; Poole and Richardson 2006; Yavari-D'Hellencourt 2000

${ }^{11}$ E.g. Flatt 2012; Giasson et al. 2010; Karim 1996; Kowalski 2013; Perigoe and Eid 2014
} 
Table 1: Newspaper Coverage by Language, Ownership and Circulation (Newspapers Canada $2014)^{12}$

\begin{tabular}{|c|c|c|c|c|}
\hline Newspaper & $\begin{array}{l}\text { Number of } \\
\text { Articles }\end{array}$ & Language & Ownership & $\begin{array}{l}\text { Average Weekly } \\
\text { Circulation }\end{array}$ \\
\hline Calgary Herald & 15 & English & Postmedia & 680,009 \\
\hline $\begin{array}{l}\text { The Edmonton } \\
\text { Journal }\end{array}$ & 8 & English & Postmedia & 597,789 \\
\hline $\begin{array}{l}\text { The Globe and } \\
\text { Mail }\end{array}$ & 6 & English & Globe and Mail Inc & $2,149,124$ \\
\hline $\begin{array}{l}\text { Le Journal of } \\
\text { Montreal }\end{array}$ & 8 & French & Quebecor & $1,633,726$ \\
\hline La Presse & 1 & French & Power Corp. of Canada & $1,633,726$ \\
\hline $\begin{array}{l}\text { Montreal } \\
\text { Gazette }\end{array}$ & 2 & English & Postmedia & 547,445 \\
\hline National Post & 13 & English & Postmedia & $1,097,080$ \\
\hline Ottawa Citizen & 7 & English & Postmedia & 626,272 \\
\hline The Province & 5 & English & Postmedia & 760,874 \\
\hline $\begin{array}{l}\text { The Vancouver } \\
\text { Sun }\end{array}$ & 3 & English & Postmedia & 869,571 \\
\hline $\begin{array}{l}\text { Telegraph } \\
\text { Journal }\end{array}$ & 1 & English & Brunswick News Inc. & 161,742 \\
\hline Toronto Star & 13 & English & Torstar Corp. & $2,397,691$ \\
\hline Windsor Star & 3 & English & Postmedia & 325,360 \\
\hline $\begin{array}{l}\text { Winnipeg Free } \\
\text { Press }\end{array}$ & 3 & English & $\begin{array}{lr}\text { FP } & \text { Canadian } \\
\text { Newspapers } & \text { Limited } \\
\text { Partnership } & \end{array}$ & 663,431 \\
\hline Le Devoir & 3 & French & Independent & 214,263 \\
\hline Times Colonist & 3 & English & Glacier Media & 330,301 \\
\hline
\end{tabular}

12 "Circulation Report: Daily Newspapers", Newspapers Canada, 2014, Accessed March 16, 2016, http://www.newspaperscanada.ca/sites/default/files/2014_Circulation_Report-

Daily_Newspapers_in_Canada_FINAL_20150603_0.pdf 


\begin{tabular}{llll}
\hline Total English & 82 & Conservative & $7,138,126$ \\
Total French & 12 & Liberal or Unknown & $7,550,278$ \\
\hline Total & 94 & Total & $14,688,404$ \\
\hline
\end{tabular}

Most articles were published by newspapers owned by the conservative-leaning Postmedia (56) and Quebecor corporations (8). However, as Table 1 shows, the coverage was more uniform in terms of circulation, with the conservative-leaning newspapers accounting for $48.5 \%$, and the liberal-leaning Globe and Mail, Toronto Star, La Presse and the remaining newspapers not associated with any political ideology accounting for $51.4 \%$ of the coverage. Hence, while more articles were published by conservative-leaning newspapers, liberal-leaning and other newspapers reached slightly more readers.

In order to analyze some "selected aspects" of the identified newspaper articles, I employed qualitative content analysis (Hsieh and Shannon 2005; Schreier 2015). After the first phase of exploratory coding showed that the majority of commentators employed gender equality to construct their arguments, in the second phase the articles were coded for references to gender (in)equality in Canada and/or among Muslims and for positions towards the ban. ${ }^{13}$ In order to examine who got to speak (Richardson 2007), the stories were coded for the presumed sex and religious background of the authors and cited sources. ${ }^{14}$ The coded references were counted in order to make quantifiers such as "some", "most" and "many" more precise (Maxwell 2010), as well as to give "a sense of how representative and widespread" certain portrayals were (Seale 2011, 128).

\section{Findings}

As Table 2 (below) shows, the majority of newspaper articles were opinion pieces (82/94), mostly letters to the editor. Over the span of a month, 49 readers expressed their opinion on the ban in 55 letters sent to Canadian newspapers. The policy thus garnered significant interest among the general public. This is not surprising, given the overall attention that the question of Muslim head and face coverings has been attracting in national and international contexts.

The majority of authors were men (53/80), and most authors were non-Muslim (66/80). What stands out is that only five of the 25 female authors were Muslim women, and all were readers who wrote letters to the newspapers. Two of those women identified as wearing the niqab. Out of 38 people who were quoted in 94 articles, only two women who cover their faces were quoted in five articles.

\footnotetext{
${ }^{13}$ A single news report often contained multiple and opposing arguments, either in the "on the one hand-on the other hand" form or through citing/quoting multiple sources. This applies to opinion pieces as well, which nonetheless, for the most part, expressed a final position either for or against the policy.

${ }^{14}$ This was determined either by using authors' and cited sources' self-identification as being of a certain sex or religious background, or by making assumptions based on their names and the content of the article. I acknowledge the possibility of error in making these assumptions.
} 
Table 2: Newspaper Coverage by the Type of Article, Gender and Religious Background ${ }^{15}$

\begin{tabular}{|c|c|c|c|c|c|}
\hline \multirow{2}{*}{$\begin{array}{l}\text { Articles } \\
\text { News Reports }\end{array}$} & \multirow[b]{2}{*}{12} & \multirow{2}{*}{$\begin{array}{l}\text { Authors } \\
\text { Female }\end{array}$} & \multirow[b]{2}{*}{4} & \multicolumn{2}{|c|}{ Religious Background } \\
\hline & & & & Muslim & 0 \\
\hline & & & & Not Muslim & 4 \\
\hline & & Male & 8 & Muslim & 0 \\
\hline & & & & Not Muslim & 8 \\
\hline & & & & Total Muslim & 0 \\
\hline & & & & Total not Muslim & 12 \\
\hline & & Total journalists & 13 & & \\
\hline \multirow[t]{7}{*}{ Columns } & 20 & Female & 6 & Muslim & 0 \\
\hline & & & & Not Muslim & 6 \\
\hline & & Male & 13 & Muslim & 2 \\
\hline & & & & Not Muslim & 11 \\
\hline & & & & Total Muslim & 2 \\
\hline & & & & Total not Muslim & 17 \\
\hline & & Total Columnists & 19 & & \\
\hline Editorials & 7 & & & & \\
\hline \multirow[t]{5}{*}{ Letters } & 55 & Female & 6 & Muslim & 5 \\
\hline & & & & Not Muslim & 10 \\
\hline & & Male & 32 & Muslim & 6 \\
\hline & & & & Not Muslim & 26 \\
\hline & & Undetermined & 2 & Muslim & 1 \\
\hline
\end{tabular}

${ }^{15}$ Two different news reports were written by the same author, hence the discrepancy between the number of news reports and the number of authors. Two different columns were written by the same author which explains the difference between the number of columns and the number of authors. Finally, several letters of similar, but not identical content were written by the same authors/readers, resulting in the discrepancy between the number of letters and the number of authors/readers. 
gender

$\begin{array}{ll}\text { Not Muslim } & 1 \\ \text { Total Muslim } & 12 \\ \text { Total not Muslim } & 37\end{array}$

\begin{tabular}{|c|c|c|c|}
\hline $\begin{array}{l}\text { Total } \\
\text { opinion } \\
\text { pieces }\end{array}$ & 82 & $\begin{array}{l}\text { Total } \\
\text { gender }\end{array}$ & 49 \\
\hline Total & 94 & Total female & 25 \\
\hline \multirow[t]{7}{*}{ articles } & & Total make & 53 \\
\hline & & Total & 2 \\
\hline & & undetermined & \\
\hline & & gender & \\
\hline & & Total Muslim & 14 \\
\hline & & Total not Muslim & 66 \\
\hline & & Total authors & 80 \\
\hline
\end{tabular}

Male, non-Muslim voices dominated the citations. As Table 3 shows, the articles cited an equal number of male and female sources. However, men were cited significantly more frequently than women (274 vs. 75). Next, 21 non-Muslim and 17 Muslim individuals were cited (Table 3). In terms of the actual frequency of citations, non-Muslims were cited 285 times and Muslims 64 times. Minister Jason Kenney was the most frequently named and cited source. While Kenney's announcement of the ban was the most frequent citation, it is still significant that Muslim voices accounted for only $18.3 \%$ of the cited sources.

Table 3: Coverage by the Gender and Religious Background of Cited Sources

\begin{tabular}{lllll}
\hline & & Number & References & Articles \\
\hline Female & Muslim & 11 & 50 & 10 \\
& Not Muslim & 8 & 25 & 12 \\
\hline
\end{tabular}




\begin{tabular}{lllll}
\hline \multirow{2}{*}{ Male } & Total & 19 & 75 & 23 \\
& Muslim & 6 & 14 & 8 \\
& Not Muslim & 13 & 260 & 63 \\
Organizations & Total & 19 & 274 & 71 \\
\hline Total & & 2 & 5 & 2 \\
\hline
\end{tabular}

Next, as Table 4 shows, 54\% of opinion pieces (editorials, columns, letters) expressed support for the policy - 45 vs. 34 , while three expressed no clear position.

In terms of position by sex, out of the 70 columnists and readers, 15 out of 24 , or $62.5 \%$ of articles authored by women, including Muslim women, were against the ban, while 33 out of 46, or $71 \%$ of male-authored articles supported it. Men were thus more likely than women to support the ban. In terms of position by religious background, more columns and letters written by nonMuslims supported the ban (37 vs. 5), while an equal number of pieces authored by Muslims and non-Muslims were opposed to it (15 and 15). Non-Muslims were thus more likely to support the ban. Interestingly, the Muslims who supported the ban were all men - mostly readers, while the Muslims who were against the ban were all women who wrote letters to the editor. Also, while overall most female-authored articles were against the ban (15/24), most articles written by nonMuslim women actually supported the policy (9/16). Non-Muslim men and women thus tended to support the ban.

Table 4: Position by Number of Articles

\begin{tabular}{llll}
\hline Pro & Editorials & 3 \\
\cline { 2 - 3 } & Female & Muslim & 0 \\
& Total & Not Muslim & 9 \\
Male & Muslim & 9 \\
& & Not Muslim & 28 \\
& Total & & 33 \\
\cline { 2 - 3 } Against & Total pro & & 45 \\
& Editorials & & 4 \\
\hline & Female & Muslim & 8 \\
\hline
\end{tabular}




\begin{tabular}{|c|c|c|c|}
\hline & & Not Muslim & 7 \\
\hline & Total & & 15 \\
\hline & Male & Not Muslim & 7 \\
\hline & Total & & 13 \\
\hline & $\begin{array}{l}\text { Undetermined } \\
\text { gender }\end{array}$ & Muslim & 1 \\
\hline & & Not Muslim & 1 \\
\hline & Total & & 2 \\
\hline & Total against & & 34 \\
\hline \multirow{5}{*}{$\begin{array}{l}\text { Undetermined } \\
\text { Position }\end{array}$} & & Muslim & 0 \\
\hline & & Not Muslim & 3 \\
\hline & & & (male) \\
\hline & Total & & 3 \\
\hline & $\begin{array}{l}\text { Undetermined } \\
\text { position }\end{array}$ & & \\
\hline Total & & & 82 \\
\hline
\end{tabular}

Finally, most articles used gender (in)equality to argue their stance towards the ban. As Table 5 shows, significantly more articles referenced gender equality than gender inequality in Canada (24 vs. 8). In contrast, inequality among Muslims was mentioned 33 times, while gender equality among Muslims was not referred to at all. Overall, gender inequality among Muslims was referenced in more articles than both gender equality and inequality in Canada. What follows is a qualitative analysis of some of these representations.

Table 5: : References to Gender (In)Equality by Number of Articles ${ }^{16}$

\begin{tabular}{|c|c|c|}
\hline $\begin{array}{l}\text { References to } \\
\text { gender } \\
\text { equality in } \\
\text { Canada }\end{array}$ & $\begin{array}{l}\text { References to } \\
\text { gender } \\
\text { inequality to } \\
\text { Canada }\end{array}$ & $\begin{array}{l}\text { References to } \\
\text { gender } \\
\text { inequality } \\
\text { among }\end{array}$ \\
\hline
\end{tabular}

\footnotetext{
16 This refers to news reports which published arguments of various commentators, but expressed no overt position of their own.
} 
Muslims

\begin{tabular}{llll}
\hline Position - Pro & 10 & 3 & 17 \\
Position - Against & 7 & 5 & 12 \\
No overall position & 7 & 0 & 4 \\
& & & \\
\hline Total & 24 & 8 & 33 \\
\hline
\end{tabular}

\section{Representations of Gender (In)Equality in Canada}

Commentators writing in favour of the ban (predominantly non-Muslim men, see Table 2) largely represented gender equality in Canada as a crucial national value and an accomplished fact. Gender equality was given as the key reason for which face-covering women should not become accepted as members of the "Canadian family", to quote Minister Jason Kenney, unless they uncover their faces during citizenship ceremony and thereby signal willingness to accept Canadian values and (eventually) become more like the gender-equal Canadian women. Being Canadian implied being gender equal. For instance, the National Post's editorial emphasized the importance of "the rule of law, equality between the sexes and social tolerance...if Canadian citizenship is to mean anything, it cannot be given away to those who flout our values". ${ }^{17}$ Corbella proclaimed that "[m]en and women are viewed as equal before the law in Canada and will not be segregated during the ceremony. If that violates someone's religious beliefs - and we know that it does - then that's the price of citizenship". 18 "Equality of the sexes" was deemed by Kay to be "one of Canada's fundamental values"19, while Warren went so far as to proclaim gender equality Canada's value since "pioneering" days when women in Canada had "the privilege of looking men in the face and vice versa. This has nothing to do with immodesty. It goes instead to the heart of the woman's place in the community". ${ }^{20}$ These commentators unequivocally championed equality between men and women, and at the same time supported the state in wanting to interfere in Muslim women's clothing practices.

While most of those against the ban also presented gender equality as Canada's key value, they also argued that it should not be used as a justification to make women uncover their faces during a citizenship ceremony. Breakenbridge contended that gender equality as a "definable" Canadian value "should not be an excuse to intrude into the private lives of citizens". ${ }^{21}$ Walkom referred to "a belief prized in this country, that women are equal to men and have the right to participate fully and publicly in all aspects of Canadian society"; however, "using the heavy

17 "Making citizenship mean something", National Post, December 13, 2011.

${ }^{18}$ Corbella Lisa, "Citizenship is privilege, not right", Vancouver Sun, December 15, 2011.

${ }^{19}$ Kay, Barbara, "Facing up to Canadian values", National Post, December 13, 2011.

${ }^{20}$ Warren, David, "Doing the right thing", Ottawa Citizen, December 14, 2011.

${ }^{21}$ Breakenbridge, Rob, "Burka restriction punishes victims", Calgary Herald, December, 20, 2011. 
hand of the state risks transforming this relatively minor dispute over ceremony into a much more intense cultural battle". ${ }^{22}$.President of the Islamic Social Services Association Shahina Siddiqui wondered if

a minister who does not comprehend the basic tenants of the women's movement in Canada where we fought long and hard to be recognized as persons under the law and struggled to gain the right to choose what we wear and how we live our lives - [should] be giving lectures on the value of Canadian citizenship? ${ }^{23}$

Far fewer references were made to gender inequality in Canada. It was mentioned by only three pro-ban opinion pieces, and only as being minimal in contrast to inequality in Muslim majority countries. For instance, Roy referred to a Maclean's story by Anne Kingston published in the month following the ban which suggested that hypersexualization of women in the West is comparable to gender oppression among Muslims. ${ }^{24}$ Having briefly and vaguely acknowledged that there were "imperfections", Roy rejected Kingston's argument by saying:

there are civilizational features that, yes, "we" can in fact judge. Those that we are familiar with, after centuries of struggles against religious or cultural madness, those that are opposed to human dignity, physical integrity, equality. Let's stop criticizing ourselves for a brief moment and realize that, on those critical points, Western civilization in general and Canadian in particular, without being perfect, has not done too badly ${ }^{25}$ (author's translation)

Gender inequality in Canada was relegated to the past by McInnes, for whom the practice of face covering "is associated with parts of the world where women have fewer rights than men, a proposition that we no longer accept in Canada" 26 . In a similar vein, Walkom, who spoke against the ban, first acknowledged that gender equality in Canada is not a done deed, only to, a couple of paragraphs later, relegate inequality to the 1950s or attribute it to Christian sects: "for the most part, Canada has managed to overcome the anti-feminism of its religious history". ${ }^{27}$

Two readers who identified as Muslim men questioned the assumption that gender equality in the West is an accomplished fact. Bessadook referred to makeup as a potentially comparable signifier of oppression in the West, "where female body parts became the hot centrepiece for every successful business. That is the real repression". ${ }^{28}$ "Women are victimized all over the world", contended Ahmed, "in Canada women still access shelters and only recently won the battle against Canada Post for equal pay. These issues aren't caused by religious dress". ${ }^{29}$ While the two commentators were the only ones not to silence or minimize gender inequality in Canada, they also rejected the notion that oppression could be at work in some instances of the practice of face covering. They opted, instead, for religious or cultural explanations of face coverings. For

\footnotetext{
${ }^{22}$ Walkom, Thomas. What's right about Jason Kenney's no veil rule, Toronto Star, December 14, 2011.

${ }^{23}$ Siddiqui, Shahina. "Lost Dignity”, Calgary Herald, December 15, 2011.

${ }^{24}$ Kingston, Anne. "Veils: Who are we to judge?", Maclean's, January 17, 2012.

${ }^{25}$ Mario Roy, "Le voile, encore", La Presse, January, 28, 2012.

${ }^{26}$ McInnes, Craig, "Facing up to multiculturalism's limits; Tories' policy on veils tests the of strength of tradition and what it means to be a Canadian". Vancouver Sun, December 14, 2011.

${ }^{27}$ Walkom, Thomas. What's right about Jason Kenney's no veil rule. December 14, 2011.

${ }^{28}$ Bessadook, Mohammed, "Veil not a sign of repression” Windsor Star, January 3, 2012.

${ }^{29}$ Ahmed, Kashif, "Veil ruling diverts attention", Toronto Star, December 17, 2011.
} 
instance, Ahmed argued that "the veil is about dignifying and protecting women, not subjugating them". 30

\section{Representations of Gender Inequality Among Muslims}

References to gender inequality among Muslims mostly included the following presumptions regarding the reasons behind wearing a face covering: 1) Muslim women are coerced into the practice by male family members, 2) multiple reasons could be at work and 3) it is a choice inspired by religion and modesty.

All commentators arguing for the ban (predominantly non-Muslim men) assumed that patriarchy and coercion were the reasons why some Muslim women cover their faces. Taking it off during citizenship ceremony would demonstrate openness to become more like the gender-equal "us". Until then, niqab-wearing women would remain not only unequal, but less human than "their" oppressive and aggressive men who would miss a valuable lesson in equality. Being "human" was equated to being gender-equal and face-covering Muslim women would remain sub-human until they uncovered their faces. Niqabs are "not only anti-woman, they are anti-social. Even anti-human. That's because veils cover the face. And the importance of the face in human psychology cannot be overstated", wrote Gardner. ${ }^{31}$ The regulation was deemed by Kay to be "a welcome first step to integrating women into their new roles as human beings who are fully equal to men, as well as sending an important message to men for whom the idea of equality between the sexes is a novel one". 32 "Most likely, their brains were washed by Muslim men for centuries. It's time for Muslim women to abandon the old habits and face the real world, particularly in Canada and in the West", contended Das. ${ }^{33}$ For Klatt, "Critics of the custom of veiling women almost exclusively talk about the denigration of women that motivates Muslim men to cover up their chattel". ${ }^{34}$

Most commentators who were opposed to the ban argued that the policy would deepen the presumed oppression of Muslim women who cover their faces. A Toronto Star editorial stated that while these women, "deliberately hold themselves aloof from the wider community and display beliefs that run counter to ideals about equality between men and women". ${ }^{35}$ The editorial goes on to say that, "full and equal" citizenship implies resisting "the impulse to punish those who are different - however much we disagree with their beliefs". ${ }^{36}$ Comparing the ban with similar laws in Europe, The Winnipeg Free Press wrote that edicts like these "are counterproductive in that they prevent some from joining in the daily life of the schools, workplaces and marketplaces where immigrants naturally and quickly integrate. That isolation breeds an alienation that reinforces oppression and inequality". 37 "Denying a woman in burqa the right to swear the oath of citizenship further isolates her from mainstream society", argued

\footnotetext{
30 Ibid.

${ }^{31}$ Gardner, Dan, "The canvas of emotion; face veils are not like any other religious garment - they are intended to smother identity, writes Dan Gardner", Ottawa Citizen, December 14, 2011.

${ }^{32}$ Kay, Barbara, "Facing up to Canadian values", National Post, December 13, 2011.

${ }^{33}$ Das, Sanat K., "Face the world", Calgary Herald, December, 21, 2011.

${ }^{34}$ Klatt, Heinz, "Niqab a problem for both sexes", National Post, December, 20, 2011.

35 "Citizenship and bigotry", Toronto Star, December 13, 2011.

36 Ibid

37 "Remove the veil from bigoted eyes", Winnipeg Free Press, December 15, 2011.
} 
Arif". ${ }^{38}$ Muslim men were presented as perpetrators of oppression by Walkom: "Perhaps the answer is for those who would veil womenfolk to voluntarily rethink their position". 39 "By banning the burka, we would be targeting those who wear it. There would be no consequences for the husbands who force their wives to wear it or the imams who warn of eternal hellfire for those who shun it", concurred Breakenridge. ${ }^{40}$

Some commentators arguing against the ban acknowledged the multiplicity of reasons behind the wearing of the niqab. While some Muslim women wear it due to coercion or social pressure, others "don traditional dress freely, sometimes for reasons of deep personal faith, sometimes to make a political or social statement", Simons declared, adding that, regardless of how we feel about it, "Why punish that minority of women who are, in fact, forced by male relatives to wear the niqab, by refusing them legal protections we freely grant to their oppressors?" 41 . Professor Felice Lifshit concurred with Simons: "[m]ost who do veil themselves do it voluntarily", however, the policy "might in fact punish most harshly the very people who are most in need of citizenship rights and protections, immigrant women from extremely patriarchal cultures". ${ }^{4}$

Most Muslim and some non-Muslim commentators argued that the practice is a personal choice and that coercion is a non-issue. This argument came almost exclusively from women, including those few Muslim women who sent letters to newspapers. Both Muslim and non-Muslim women were portrayed as free to make choices regarding what to wear. Rana, a self-identified Muslim woman, argued that the niqab is a "mechanism of emancipation that liberates women from the bondage of all sorts of body-baring and self-degradation". ${ }^{43}$ Mina Ella was quoted as insisting she did not cover her face because she was oppressed, but for the sake of religion and modesty. ${ }^{44}$ Head of the Muslim Council of Montreal Salam Elmenyawi was also cited as saying that "a woman who chooses to cover her face is doing so because she believes it is the best way for her to live her faith". ${ }^{45}$ Fatema Nakhuda, a self-identified Muslim woman, argued none of the "many other Muslim women who choose to wear the veil" that she personally knew would object to showing their face for citizenship purposes: "Unfortunately, the ramification of this fanfare acts to pit Canadians against each other, and incite animosity against Canadian Muslims". 46 "Though many view the veils as a sign of oppression, they actually signify the ideologies of modesty and chastity", wrote Nicole Moore, a self-identified non-Muslim reader. She added that "In a westernized culture, where youth admire the morally corrupt television stars like the cast of Jersey Shore, how can we discredit these women's choices to cover themselves as a sign of personal dignity? I feel strongly about respecting the choices of others and encouraging cultural

\footnotetext{
38 Arif, Hassan, “Jason Kenney got it wrong”, Telegraph Journal, December 19, 2011.

${ }^{39}$ Walkom, Thomas. What's right about Jason Kenney's no veil rule. INSERT PUBLISHER, December 14, 2011.

${ }^{40}$ Breakenbridge, Rob, "Burka restriction punishes victims", Calgary Herald, December, 20, 2011.

${ }^{41}$ Simons, Paula, "Slight of Muslim women is cynical politics; Kenney's ban on veils for citizenship targets nonproblem”, Edmonton Journal, December 13, 2011.

${ }^{42}$ Lifshitz, Felice, "Policy against veils could punish people most in need of rights", Edmonton Journal, December 19, 2011.

${ }^{43}$ Rana, Inaam, “Defining the veil”, Ottawa Citizen, December 17, 2011.

${ }^{44}$ Smith, Theresa, "Niqab ban raises fears of a less-tolerant Canada; survey shows 81 per cent agree with ban", Calgary Herald, December 17, 2011.

${ }^{45}$ Harrold, Max, "Ottawa bans face veils at citizenship ceremonies; Muslim groups fear implications; move 'necessary' to properly identify women being sworn in, Kenney says", The Gazette, December 13, 2011.

${ }^{46}$ Nakhuda, Fatema, "Veil ruling diverts attention", Toronto Star, December 17, 2011.
} 
and racial respect" ${ }^{\prime 7}$. Choice, not oppression or gender socialization, guide women's actions; this applies to Muslim and non-Muslim women alike, argued Southey. If "high heels and miniskirts" 48 are a personal choice, and not a sign of objectification and degradation, there is no reason why a woman cannot also choose to cover her face. "I refuse to make those assumptions and I regret any rule that enshrines them. Just as I ask those assumptions not be made about me, based on my shoes. Click, click, click" (Ibid).

\section{Discussion and Conclusion}

This paper examined the way that gender equality was employed by Canada's mainstream newspapers to argue their positions regarding the ban of face coverings during citizenship ceremonies and asked how they conceptualized the meaning of Canadian citizenship. The findings show that most commentators erased gender inequality among "us", and ascribed it instead to "them". Both women and men, Muslims and non-Muslims, those in favour and those opposed to the ban employed strikingly similar logic while constructing opposing arguments. Canadian citizenship was represented either as 1) an award for already being or 2) an instrument for becoming neoliberal.

It was primarily men - judging by their names presumably white and of Christian-backgroundwho employed gender equality to voice their opposition to face coverings. From Minister Jason Kenney to male readers, the central theme was their concern for and apparent need to rescue niqab-wearing women from their oppressive male family members. The women were portrayed in broad strokes as without agency: dependent, unfree to making choices and less human. This is in keeping with what Spivak $(1988,296)$ termed "white men saving brown women from brown men". By representing Muslim (non-Canadian) men as the enforcers of the non-neoliberal niqab, the white, Christian-background men implicitly cast themselves as liberal, progressive and too respectful towards women to be able inflict gender-based oppression. However, the Muslim male readers also cast themselves as face-covering Muslim women's saviours from the gender inequality of Western societies. Being placed in a position to defend their culture, the Muslim commentators may have felt that acknowledging gender inequalities to any measure would have validated the assumption that gender oppression is rampant among Muslims. The reproduction of "us" vs. "them" categories, however, only served to perpetuate the perceived cultural divide and bolster the discursive erasure of gender inequality at large. By appropriating the oppression vs. freedom of choice binary, both Muslim and non-Muslim men erased the existence of gender inequality among "their" women. They redirected the "we are not oppressive, you are" argument against each other, and thereby silenced the intersecting experiences of oppressions and choices of all women, regardless of their background or immigration status.

Most female commentators-also presumably white, Christian-background and in the case of the columnists, educated, middle class and privileged-employed similar arguments to portray niqab-wearing women. This illustrates what Abu-Lughod, paraphrasing Spivak, termed "white women saving brown women from brown men" $(1998,14)$. This logic constructs "us" (Western,

\footnotetext{
${ }^{47}$ Moore, Nicole, "Cultural respect", Calgary Herald, December 20, 2011.

${ }^{48}$ Southey, Tabatha, "Minister Kenney, can I become a citizen in these shoes?", Globe and Mail, December 17, 2011
} 
non-Muslim women) as, "educated, modern, having control over their own bodies and sexualities, and the freedom to make their own decisions" (Mohanty 1991, 56). This erases the existence of inequality among non-Muslim, and more generally Canadian and Western women. However, Muslim female commentators also, albeit using different arguments, employed similar neoliberal arguments which posited Muslim women who cover their faces invariably choose to do so. They disregarded the possibility of oppression being at work in some instances of the practice and represented face coverings as an emancipation from gender oppression in the West. In an attempt to subvert prevalent assumptions about gender inequality among Muslims, the Muslim women represented Canadian citizenship as a reward for already being neoliberal. A few of them presented the information that they were born or raised in Canada as evidence that it is possible to be Canadian and choose to wear a head or face covering. Using the "privilege" of being Canadian, Muslim and/or wearing a head or face covering, they generalized their being in a position to choose to all Muslim women who cover their faces. Thus, solely by virtue of their being capable of and free to make choices, niqab-wearing Muslim women-prospective Canadians - were represented as already neoliberal and hence deserving to be accepted into the Canadian family.

For those in favour of the ban, regardless of their sex or religious background, displaying nonneoliberal beliefs (signified by wearing a face covering) during citizenship ceremony meant not qualifying for Canadian citizenship. Uncovering faces would signal willingness to eventually become liberated. For those against the ban, accepting face-covering women into citizenship meant awarding them an opportunity to eventually shed their non-neoliberal beliefs. Citizenship was presented as a tool that would, in the long run, lead to face-covering Muslim womens' freedom from patriarchal oppression and assimilation with the gender-equal "us". The difference between the commentators for the ban and most of those against it was primarily in the timing. For the former the emancipation should occur either before or, at least, be enacted during the ceremony, while for the latter group the granting of citizenship would help facilitate the eventual rescuing of niqab-wearing Muslim women from oppression.

Not only do these representations position face-covering Muslim women outside Canadian citizenship and deepen the perception of unsurmountable differences between "us" and "them", they mark the unequal and the oppressed (via their erasure) as unworthy of both media attention and citizenship. This has important implications for the struggle for gender equality in Canada. As noted earlier, the mainstream media play a major role in asserting dominant narratives and prioritizing agendas. The press coverage purported to take gender equality seriously, but only insofar as the nation's "others" are concerned. Presenting gender equality as an accomplished fact and trivializing or rendering invisible instances of gender inequality outside of Muslim communities has practical bearings, whether in the realm of everyday life or policymaking. The centering on the "real" gender inequalities of "others", Muslims in particular, renders "our" grievances trivial at best, nonsensical at worst. It ignores lived experiences of inequality of all women and perpetuates the silence on the state of gender equality in Canada at the expense of both "us" and Muslim "others". Through insisting on individualism and personal choice and through separating "us" from "them", the media deter women from finding common cause and "makes unlikely the forging of alliances, affiliations or connections," in local, national or international contexts (McRobbie 2009, 2). 


\section{REFERENCES}

Abu-Laban, Yasmeen and Christine Gabriel. 2002. Selling diversity, immigration, multiculturalism, employment equity, and globalization. Peterborough: Broadview Press.

Abu-Laban, Yasmeen. 2013. On the borderlines of human and citizen. In Jenna Hennebry and Bessma Momani (eds.), Targeted transnationals, the state, the media, and Arab Canadians. Vancouver: UBC Press, 68-88.

Abu-Lughod, Lila. 1998. Remaking women: Feminism and modernity in the Middle East. Princeton: Princeton University Press

Ahmed, Leila. 2011. A quiet revolution: The veil's resurgence from the Middle East to America. New Haven: Yale University Press.

Anderson, Bridget. 2013. Us and them? The dangerous politics of immigration control. London: Oxford University Press.

Bilge, Sirma. 2008. Between gender and cultural equality. In Engin Fahri Isin (ed.), Recasting the social in citizenship. Toronto: University of Toronto Press, $100-133$.

Bleich, Erik, Hannah Stonebraker, Hasher Nisar, and Rana Abdelhamid. 2015. "Media portrayals of minorities: Muslims in British newspaper headlines, 2001-2012". Journal of Ethnic and Migration Studies, 41(6), 942-962.

Borghée, Maryam. 2012. Voile intégrale en France: Sociologie d'un paradox. Paris: Éditions Michalons.

Bowen, John. 2007. Why the French don't like headscarves: Islam, the state and public space. Princeton: Princeton University Press.

Brodie, Janine. 2008. Putting gender back in: Women and social policy reform in Canada. In Yasmeen Abu-Laban (ed.), Gendering the nation-state, Canadian and comparative perspectives. Vancouver: UBC Press, 165-184.

Bullock, Katherine and Gul Joya Jafri. 2001. "Media (mis)representations: Muslim women in the Canadian nation". Canadian Woman Studies, 20(2) 35-40.

Byng, Michelle. 2010. "Symbolically Muslim: Media, hijab, and the West”. Critical Sociology, 36(1) 109-129.

Canada. 2011. Discover Canada: The rights and responsibilities of citizenship. Government of Canada: Citizenship and Immigration Canada: Public Works and Government Services Canada.

Citizenship and Immigration Canada. 2011a. Operational bulletin 359 - December 12, 2011. Retrieved 04/15 2014, from http://www.cic.gc.ca/english/resources/manuals/bulletins/2011/ob359.asp

Citizenship and Immigration Canada. 2011b. Speaking notes for The Honourable Jason Kenney, P.C., M.P. Minister of Citizenship, Immigration and Multiculturalism. Retrieved 04/15 2014, from http://www.cic.gc.ca/english/department/media/speeches/2011/2011- 1212.asp

Clarke, Lynda. 2013. Women in the niqab speak, A study of the niqab in Canada. The Canadian Council of Muslim Women. 
Fernandez, Sonya. 2009. "The crusade over the bodies of women". Patterns of Prejudice, 43: 3-4, 269286.

Ferrao, Vincent. 2010. Paid work. Ottawa, Statistics Canada.

Fekete, Liz. 2004. "Anti-Muslim racism and the European security state”. Race \& Class, 46(1)3-29.

Fleras, Augie and Jean Lock Kunz. 2001. Media and minorities: Representing diversity in a multicultural Canada. Toronto: Thompson Educational Pub.

Fleras, Augie. 2011. The media gaze: Representations of diversities in Canada. Vancouver: UBC Press.

Fredette, Jennifer. 2014. Constructing Muslims in France: Discourse, public identity, and the politics of citizenship. Philadelphia: Temple University Press.

Freedman, Jane. 2006. The headscarf debate, Muslim women in Europe and the 'War on terror'. In Krista Hunt, and Kim Rygiel (eds.), Engendering the war on terror, War stories and camouflaged politics. Aldershot: Ashgate, 169-190.

Gagnon, Monika Kin and Yasmin Jiwani. 2012. Amplifying threat, reasonable accommodations and Quebec's Bouchard-Taylor commission hearings 2007. In Smaro Kamboureli and Robert Zacharias (eds.), Shifting the ground of Canadian literary studies. Waterloo: Wilfrid Laurier University Press, 129-150.

Gallagher, Margaret. 2013. Media and the representation of gender. In Cynthia Carter, Linda Steiner and Lisa McLaughlin (eds.), The Routledge companion to media and gender. New York: Routledge, 2331.

Geisser, Vincent. 2003. La nouvelle islamophobie. Paris: La Découverte.

Gupta, Rahila. 2012. “Has neoliberalism knocked feminism sideways?” Retrieved 4/15 2014, from http://www.opendemocracy.net/5050/rahila-gupta/has-neoliberalism-knocked-feminism-sideways

Harvey, David. 2007. A brief history of neoliberalism Oxford: Oxford University Press.

Henry, Frances and Carol Tator. 2002. Discourses of domination: Racial bias in the Canadian Englishlanguage press. Toronto: University of Toronto Press.

Hoodfar, Homa. 2003. More than clothing, Veiling as an adaptive strategy. In Homa Hoodfar, Sheila McDonough and Sajida Alvi (eds.), The Muslim veil in North America: Issues and debates. Toronto: Women's Press, 3-39.

Hsieh, Hsiu-Fang and Sarah Shannon. 2005. Three approaches to qualitative content analysis. Qualitative Health Research, 15(9), 1277-1288.

Jenson, Jane 2008. Citizenship in the era of "new social risks": What happened to gender inequalities? In Yasmeen Abu-Laban (ed.), Gendering the Nation-State: Canadian and Comparative Perspectives. Vancouver: UBC Press, 185-201.

Jenson, Jane and Ron Levi. 2013. Narratives and regimes of social and human rights: The Jackpines of the neoliberal era. In Michelle Lamont and Peter Hall (eds.), Social resilience in the neoliberal era. New York: Cambridge University Press, 69-98. 
Jiwani, Yasmin. 2008. Gendered violence within and across the borders. In Katharine Sarikakis and Leslie Regan Shade (eds.), Feminist interventions in international communication: Minding the gap. Lanham: Rowman \& Littlefield, 129-144.

Karim, Karim H. 2002. Crescent dawn in the great white north, Muslim participation in the Canadian public sphere. In Yvonne Yazbeck Haddad (ed.), Muslims in the West: From sojourners to citizens. Oxford: Oxford University Press, 262-277.

Mahtani, Minelle. 2001. "Representing minorities: Canadian media and minority identities". Canadian Ethnic Studies, 33(3), 99-133

Mautner, Gerlinde. 2008. Analyzing newspapers, magazines and other print media. In Ruth Wodak and Michal Krzyzanowski (eds.), Qualitative discourse analysis in the social sciences. New York: Palgrave Macmillan, 30-53.

Maxwell, Joseph. 2010. "Using numbers in qualitative research”. Qualitative Inquiry, 16(6) 475482.

McCombs, Maxwell and Donald Shaw. 1972. "The Agenda-Setting Function of Mass Media”. Public Opinion Quarterly, 36: 176-87.

McDonough, Sheila and Homa Hoodfar. 2005. Muslims in Canada: From ethnic groups to religious community. In Paul Bramadat and David Seljak (eds.), Religion and ethnicity in Canada. Toronto: Pearson Longman, 133-153.

McDonough, Sheila. 2003a. Perceptions of the hijab in Canada. In Homa Hoodfar, Sheila McDonough and Sajida Alvi Eds (eds.), The Muslim veil in North America: Issues and debates. Toronto: Women's Press, 121-142.

McDonough, Sheila. 2003b. Voices of Muslim Women. In Homa Hoodfar, Sheila McDonough and Sajida Alvi Eds (eds.), The Muslim veil in North America: Issues and debates. Toronto: Women's Press, 105-120.

McGarry, Karen Ann and Lynda Mannik. 2015. Reclaiming Canadian bodies: Representation and visual media. Waterloo: Wilfrid Laurier University Press.

McRobbie, Angela. 2009. The aftermath of feminism: Gender, culture and social change. London: SAGE.

Meer, Nasar. 2006. “'Get off your knees': Print media public intellectuals and Muslims in Britain”. Journalism studies, 7(1), 35-59.

Mendoza, Breny. 2016. Coloniality of gender and power: From postcoloniality to decoloniality. In Lisa Disch and Mary Hawkesworth (eds.), The Oxford handbook of feminist theory. New York: Oxford University Press, 100-121.

Milan, Anne, Leslie Anne Keown and Covadonga Robles Urquijo. 2011. Families, living arrangements and unpaid work. Ottawa, Statistics Canada.

Mohanty, Chandra Talpade. 1991. Under Western eyes: Feminist scholarship and colonial discourses. In Mohanty, Chandra Talpade. Ann Russo, Ann and Lourdes Torres (eds.), Third World Women and the Politics of Feminism. Indiana: UP, 51-80.

Park, Augustine. 2013. "Racial-nationalism and representations of citizenship: The recalcitrant alien, the citizen of convenience and the fraudulent citizen". Canadian Journal of Sociology, 38(4) 579-600. 
Petley, Julian and Robin Richardson, Robin. 2011. Pointing the finger: Islam and Muslims in the British media. Oxford: Oneworld.

Poole, Elizabeth and John Richardson. 2006. Muslims and the news media. London: I. B. Tauris.

Provost, Rene. 2015. Mapping the legal boundaries of belonging: Religion and multiculturalism from Israel to Canada. New York: Oxford University Press.

Rajiva, Mythili and Amar Khoday. 2014. Peddling the margins of gender-based violence: Canadian media coverage of honour killings. In Jennifer Kilty (ed.), Within the confines: Women and the law in Canada. Toronto: Canadian Scholars' Press Inc, 174-202.

Razack, Sherene. 2007. “The 'Sharia law debate' in Ontario, The modernity/premodernity distinction in legal efforts to protect women from culture”. Feminist Legal Studies, 15, 3-32.

Richardson, John. 2007. Analysing newspapers: An approach from critical discourse analysis. New York: Palgrave Macmillan.

Roald, Annie Sofie. 2002. From "People's home" to "multiculturalism": Muslims in Sweden. In Yvonne Yazbeck Haddad (ed.), Muslims in the West, From sojourners to citizens. Oxford: Oxford University Press, 101-120.

Ruby, Tabassum F. 2006. "Listening to the voices of hijab". Women's Studies International Forum, 291, 54-66.

Said, Edward. 1979. Orientalism. New York: Vintage Books.

Schreier, Margrit. 2015. Qualitative content analysis. In Uwe Flick (ed.), The SAGE handbook of qualitative data analysis. Sage Publications Ltd. UK, 170-183.

Seale, Clive. 1999. The quality of qualitative research. London: SAGE Publications

Shachar, Ayelet. 2015. Law, religion and gender. In Silvio Ferrarri (ed.), The Routledge Handbook of Law and Religion. New York: Routledge, 321-335.

Somers, Margaret R. 2008. Genealogies of citizenship, markets, statelessness, and the right to have rights. New York: Cambridge University Press.

Spivak, Gayatri Chakravorty. 1988. Can the subaltern speak? In Cary Nelson and Lawrence Grossberg (eds.), Marxism and the Interpretation of Culture. Urbana: University of Illinois Press, 271-313.

Status of Women. 2015. Fact Sheet: Girls and Young Women by the Numbers. Retrieved 12/19 2015 from http://www.swc-cfc.gc.ca/initiatives/girls-filles/fs-fi-eng.html.

Sue, Derald Wing. 2010. Microaggressions and marginality: Manifestations, dynamic, and impact. Hoboken: Wiley.

The Pay Equity Commission. 2012. Gender wage gap. Retrieved 4/15 2014, from http://www.payequity.gov.on.ca/en/about/pubs/genderwage/wagegap.php

Thobani, Sunera. 2007. Exalted subjects: Studies in the making of race and nation in Canada. Toronto: University of Toronto Press. 
Thomas, Jasmine. 2015. "Only if she shows her face: Canadian media portrayals of the niqab ban during citizenship ceremonies”. Canadian Ethnic Studies/Etudes ethniques au Canada, 43(2), 187-201.

Van Dijk, Teun A. 1991. Racism and the Press. London: Routledge

Vosko, Leah. 2003. Gender differentiation and the Standard/Non-standard employment distinction, A genealogy of policy interventions in Canada. In Danielle Juteau (ed.), Social differentiation patterns and processes. Toronto: University of Toronto Press, 25-80.

Weaver, David H. 2007. "Thoughts on agenda setting, framing, and priming. Journal of Communication, 57(1) 142-47.

Winter, Elke and Marie-Michèle Sauvageau. 2014. "Vers une compréhension nationaliste de la naturalisation au Canada? Analyse des changements récents en matière d'octroi de la citoyenneté dans le contexte canadien". Canadian Journal of Law and Society/La Revue canadienne Droit et Société. 30(1) 73-90.

Wolf, Naomi. 1990/2002. The beauty myth. Mississauga: Random House Canada.

Yavari- D'Hellencourt, N. 2000. "Diabolisation" et "normalisation" de l'Islam; Une analyse dudiscours télévisuel en France', in Pierre Brechon and Jean-Paul Willaime (eds), Médias et religions en miroir. Paris: Presses universitaires de France.

Yeğenoğlu, Meyda. 1998. Colonial fantasies: Towards a feminist reading of Orientalism. Cambridge: Cambridge University Press. 
Published by the Centre for European Studies at Carleton University, Ottawa, Canada Available online at: journals.carleton.ca/rera/index.php/rera

RERA is an electronic academic peer-reviewed journal. Topics relate to the European Union, its Member States, the former Soviet Union, and Central and Eastern Europe. The journal is a joint project supported by the Canada-Europe Transatlantic Dialogue - a cross-Canada research network supported by the Social Sciences and Humanities Research Council of Canada (SSHRC) - along with the Institute of European, Russian and Eurasian Studies (Carleton University) and its associated research unit, the Centre for European Studies.

RERA aims to provide an accessible forum for research, to promote high standards of research and scholarship, and to foster communication among young scholars.

\section{Contact:}

Carleton University

The Centre for European Studies

1103 Dunton Tower

1125 Colonel By Drive

Ottawa, ON K1S 5B6

Canada

Tel: +01 613 520-2600 ext. 3117; E-mail: rera-journal@ carleton.ca

\section{Creative Commons License}

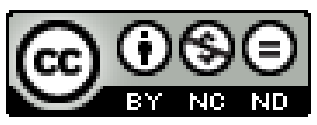

creativecommons.org/licenses/by-nc-nd/3.0

This Working Paper is licensed under a Creative Commons Attribution-Non-CommercialNo Derivs 3.0 Unported License (CC BY-NC-ND 3.0).

Articles appearing in this publication may be freely quoted and reproduced, provided the source is acknowledged. No use of this publication may be made for resale or other commercial purposes.

ISSN: 1718-4835

(C) 2017 The Author(s) 